\title{
Eerlijk (be)loon(d)?
}

\section{Vertrouwen in beloningsmanagement ten tijde van crisis}

Peggy De Prins, Sonja Brouwers, Linda Mertens \& Jesse Segers

Hoe eerlijk worden beloningspraktijken bevonden door Vlaamse werknemers ten tijde van crisis? Wordt het werknemersvertrouwen aangetast door de crisis en zo ja, kan het beloningsbeleid dit vertrouwen herstellen? Welke impact heeft vertrouwen op het engagement van werknemers en is er een verband met verloopintentie? Deze vragen vormden de centrale insteek van de Engagement Study 2009, een gemeenschappelijk initiatief van de Universiteit Antwerpen Management School en Hay Group. De bevraging gebeurde web based in januari - februari 2009, een periode waarin de economische terugval in vrijwel alle sectoren voelbaar was. Bijna 7.000 respondenten vulden de enquête in.

Het concept 'werknemersvertrouwen' kent reeds een lange traditie binnen het domein van Organisational Behaviour. In de beginperiode van het onderzoek en de theorievorming lag de focus op distributieve rechtvaardigheid, of nog de rechtvaardigheid van de uitkomst van een beslissing (Ambrose, 2002; Colquitt et al., 200I; Greenberg, I990). Later in de tijd verschoof de aandacht naar procedurale rechtvaardigheid: de rechtvaardigheid van het proces dat leidt naar bepaalde uitkomsten.

\section{Distributieve rechtvaardigheid}

De equity theory van Adams (I965) werd en wordt nog vaak in één adem genoemd met dit concept van distributieve rechtvaardigheid. De theorie houdt in dat mensen de ratio's van hun eigen uitkomsten en de input die zij erin gestopt hebben, vergelijken met ratio's van anderen. Werknemers gaan zich ook gedragen naar deze vergelijking. Als blijkt dat een werknemer veel meer inspanningen verricht heeft dan zijn collega's maar er net zoveel of minder voor terugkrijgt, zal dit betekenen dat hij zijn input of betrokkenheid zal verlagen. Andersom, als werknemers het gevoel hebben te weinig input in het werkproces te stoppen en er een te hoge uitkomst tegenover staat, dan zullen zij hun prestatie bijstellen en harder gaan werken. Het gaat dus niet om de absolute uitkomst die werknemers ontvangen, maar wat ze ontvangen in vergelijking met andere werknemers.
Prof. dr. P. De Prins is verbonden aan de Antwerp Management School.

S. Brouwers is consultant bij Hay Group Belgium. L. Mertens en J. Segers zijn als onderzoekers verbonden aan de Universiteit Antwerpen. 
Gelinkt aan het HR-domein van beloning, wordt distributieve rechtvaardigheid vaak geconcretiseerd in termen van interne billijkheid en externe competitiviteit (Lievens, 2007). Interne billijkheid verwijst dan naar vergelijking tussen functies of competentieniveaus binnen één enkele organisatie. Het betreft de vraag of het loon het relatieve belang van de vereiste taken, vaardigheden, verantwoordelijkheden en andere vereisten in de organisatie op een billijke manier weerspiegelt. Externe competitiviteit heeft op zijn beurt te maken met vergelijking tussen organisaties die dezelfde soort personeelsleden selecteren en tewerkstellen en hierdoor met elkaar concurreren om arbeidskrachten. Een belangrijke beslissing bij het uitbouwen van een beloningssysteem is immers of men het personeel evenveel ('match'), meer ('lead') of minder ('lag') betaalt dan de concurrenten. Dit is een belangrijke beslissing aangezien ze enerzijds gevolgen heeft voor de loonmassa die een organisatie uitgeeft en anderzijds voor het gemak waarmee de organisatie mensen kan aantrekken en behouden in vergelijking met haar concurrenten.

Eerder onderzoek (Hanisch \& Hulin, I990; Finn \& Lee, I972) laat uitschijnen dat een daling in engagement of commitment aan de organisatie een mogelijke reactie is op percepties van distributieve (interne/externe) onrechtvaardigheid. Ander onderzoek (De Boer et al., 2002; Hendrix \& Spencer, I989) toont bovendien een verband met psychische gezondheidsklachten en ziekteverzuim aan. De Boer et al. (2002) beargumenteren dat onderliggend vaak een stressproces of een proces van terugtrekking aan de orde is. Wanneer werknemers in de lijn van Adam's theorie een gevoel van onrechtvaardigheid ervaren, gaan zij zich (in meer of mindere mate) distantiëren van het werk/de organisatie (input verlagen) om dit gevoel van onrechtvaardigheid te compenseren. Of werknemers ervaren de onrechtvaardigheid als bijzonder stressvol en lopen op die manier het risico van inputverlaging als gevolg van psychische gezondheidsklachten en/of ziekteverzuim.

\section{Procedurale rechtvaardigheid}

Naast distributieve rechtvaardigheid bestaat er ook procedurale rechtvaardigheid. In de jaren tachtig werd duidelijk dat niet alleen de uitkomsten een rol spelen bij het bepalen van de rechtvaardigheid, maar ook het proces waarmee de uitkomsten bepaald worden. De aandacht verschoof van distributieve naar procedurele rechtvaardigheid (Wierks, 2006). Procedurale rechtvaardigheid wordt omschreven als het rechtvaardig zijn van de procedures die tot bepaald uitkomsten leiden (Ambrose, 2002; Colquitt et al., 200I; Greenberg, I990). Aan het licht kwam bijvoorbeeld dat werknemers negatieve uitkomsten eerlijker vinden als ze het gevoel hadden dat het proces eerlijk verlopen is. Een groot aantal auteurs (zie o.a. Ambrose, 2002; Colquitt et al., 2001; Greenberg, I990) hebben zich in dit kader beziggehouden met het opstellen van een aantal regels om 
procedurale rechtvaardigheid te faciliteren. Om een aantal voorbeelden te noemen:

I. procedures moeten consistent zijn voor verschillende mensen en door de tijd heen,

2. procedures moeten vrij zijn van fouten, en

3. men moet er zeker van zijn dat er correcte informatie verzameld en gebruikt wordt in het proces.

\section{Vertrouwen}

Recenter in de tijd werd het concept vertrouwen een onderzoeksthema op zich. Midden jaren negentig groeide de interesse in dit concept vanuit verschillende onderzoeksdomeinen (o.a. psychologie, organisatiegedrag, economie, sociologie), gevoed door recente overheids- en organisatieschandalen (Schoorman et al., 2007). Een beter begrip van het concept vertrouwen drong zich op. Een veelgebruikte definitie van vertrouwen is die van Mayer, Davis en Schoorman (I995: 712): 'vertrouwen is de bereidheid van iemand om zich kwetsbaar op te stellen voor de acties van een ander, gebaseerd op de verwachting dat de andere een bepaalde actie zal ondernemen, ongeacht de mogelijkheid om de andere partij te controleren'. Een werknemer is bijgevolg bereid een bepaalde inspanning te leveren als hij of zij erop vertrouwt ook beloond te zullen worden voor dit positieve gedrag. Vertrouwen leidt tot een sociale uitwisselingsrelatie tussen de werknemer en de organisatie en/of de leidinggevende. Als de ene partij (de organisatie of de leidinggevende) de andere partij (werknemer) goed en eerlijk behandelt, zal er vertrouwen ontstaan en kan er een sociale uitwisselingsrelatie worden opgebouwd (Aryee et al., 2002). De perceptie van distributieve en procedurale rechtvaardigheid creëert dus vertrouwen in de organisatie of de leidinggevende (Aryee et al., 2002). Dirks en Ferrin (200I) argumenteren dat vertrouwen attituden, gedragingen en performantie uitkomsten

Reeds drie maal op rij is in Vlaanderen op grote schaal een Engagement Study uitgevoerd niet direct beïnvloeden, maar eerder indirect door het scheppen van condities waaronder samenwerking, hogere performantie en meer positieve attituden en gedragingen sneller zullen plaatsvinden. Als werknemers de organisatie of de leidinggevende vertrouwen, voelen ze zich veiliger waardoor ze zich meer kunnen focussen op of inzetten voor hun werk, wat op zijn beurt kan leiden tot meer engagement (Kahn, I990; May et al. 2004) en een lagere verloopintentie (Aryee et al., 2002; Dirks, Ferrin, 2002).

\section{Engagement Study 2009}

Reeds drie maal op rij is in Vlaanderen op grote schaal een Engagement

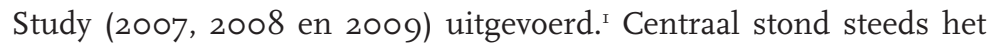
concept van 'engagement' of nog de mate van vitaliteit (beschikken over 
grote veerkracht en doorzettingsvermogen), van toewijding (sterke betrokkenheid bij het werk) en van absorptie (volledig in het werk kunnen opgaan) (Schaufeli \& Bakker, 200I). In de definitie wordt engagement beschouwd als state. Het concept engagement wordt met andere woorden van een zelfde orde beschouwd als de concepten commitment of empowerment. Kenmerkend is dat ze voor verandering vatbaar zijn en door contextfactoren (waaronder HR-beleid) beïnvloedbaar en ontwikkelbaar zijn. Macey \& Schneider (2008) onderscheiden daarnaast nog 'trait engagement' (wat engagement op een zelfde lijn brengt met persoonlijkheidstrekken als bijvoorbeeld proactiviteit of consciëntieusheid e.d. en 'behavioral engagement' (waarbij engagement vergelijkbaar wordt met het concept 'organizational citizenship behavior'). In wat volgt wordt engagement verder beschouwd als state.

Naast engagement wordt ook verloopintentie als centrale afhankelijke variabele opgenomen. Zowel het 'binden-' als 'boeienvraagstuk van werknemers werd op die manier als thema's afgedekt. Uit de eerste Engagement Study (De Prins et al., 2007 ) kwam naar voren dat beloningspraktijken vooral impact hebben op het binden van werknemers. Reden om in de Engagement Study 2009 hierop verder in te zoomen. Het onderzoeksmodel zoals gepresenteerd in figuur I fungeerde hierbij als leidraad. De centrale onderzoeksvraag luidde als volgt:

Wat is de impact van eerlijke beloningspraktijken anno 2009 op het engagement en de verloopintentie van werknemers? Hoe verhouden percepties van vertrouwen, procedurale en distributieve rechtvaardigheid zich ten opzichte van beide thema's?

Vanuit het eerder aangehaalde onderzoek verwachtten we dat beide vormen van rechtvaardigheid een positieve impact hebben op zowel het binden als het boeien van medewerkers. Geïnspireerd door de resultaten van onze eerste Engagement Study vermoedden we dat de impact op retentie hoger is dan die op engagement. Daarnaast werd nog enkele afgeleide onderzoeksvragen geformuleerd:

Welke verwachtingen leven er bij werknemers ten aanzien van het beloningsbeleid ten tijde van crisis? Hoe zien zij de toekomst tegemoet? Moet HR vooral innoveren op beloning? Of zijn werknemers eerder behoudensgezind wat hun beloning betreft?

De bijkomende onderzoeksvragen hadden vooral de bedoeling enkele beleidssuggesties naar de toekomst toe te kunnen formuleren. Door te polsen naar de voorkeuren van werknemers kunnen (voorzichtige) trends naar de toekomst worden weergegeven. 


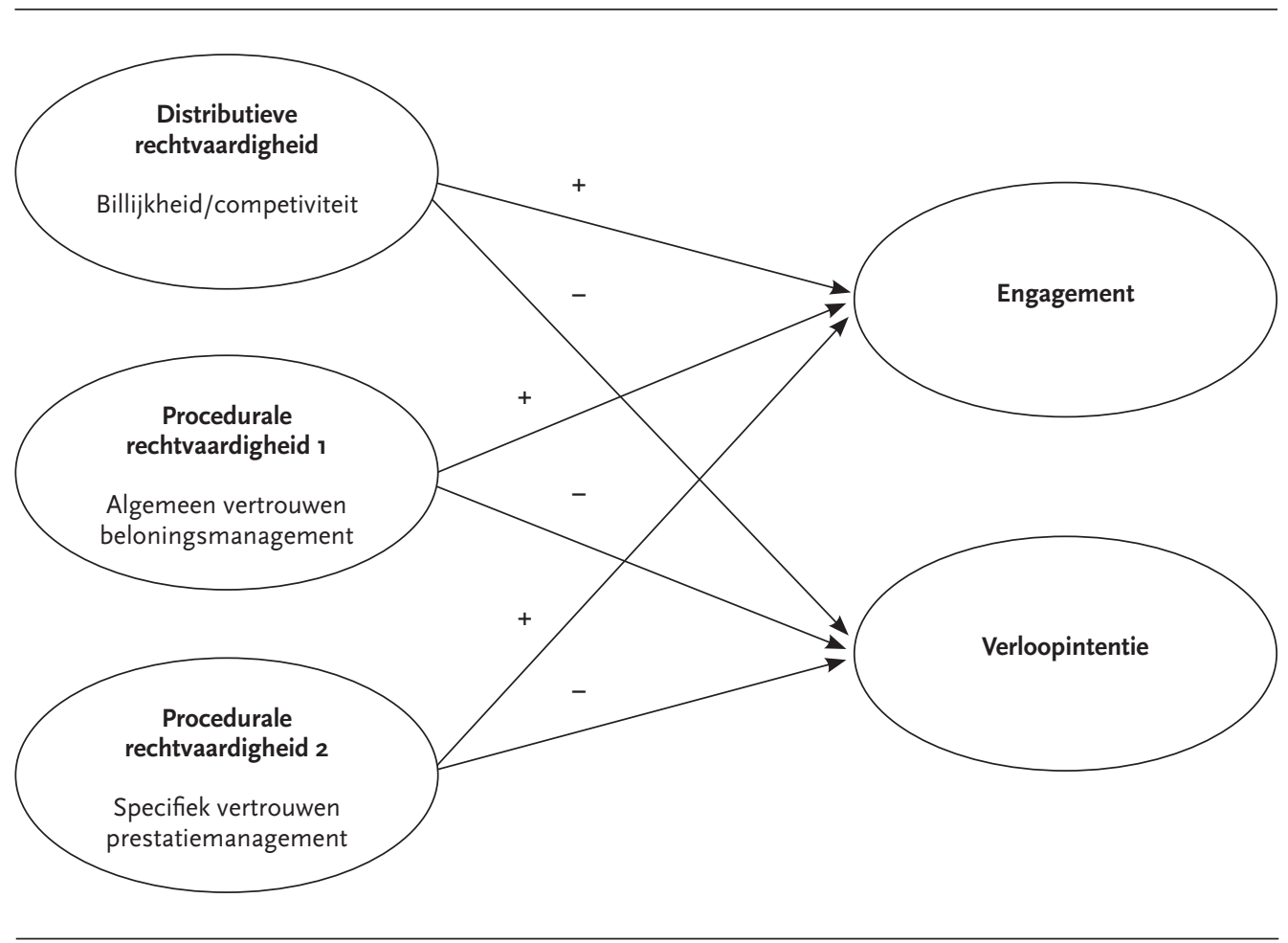

Figuur 1. Onderzoeksmodel.

Om zicht te krijgen op deze onderzoeksvragen werd een vragenlijst geconstrueerd. We gebruikten de werkbelevingsvragenlijst UBES-9 van Schaufelli en Bakker (2003) om engagement of bevlogenheid in beeld te brengen. Negen items peilen naar de mate van vitaliteit (beschikken over grote veerkracht en doorzettingsvermogen), toewijding (sterke betrokkenheid bij het werk) en absorptie (volledig in het werk kunnen opgaan). Verloopintentie werd op basis van volgende vragen in kaart gebracht: 'Hebt $u$ het afgelopen jaar overwogen om naar een andere job uit te kijken?'; 'Hebt $\mathrm{u}$ gesolliciteerd voor een functie buiten de organisatie in het afgelopen jaar?’. De andere vragen hadden betrekking op werknemersvertrouwen (of percepties met betrekking tot procedurale rechtvaardigheid). Hier werd een onderscheid gemaakt tussen algemeen vertrouwen in beloningsbeleid en specifiek vertrouwen in prestatiemanagement. De invulling van beide percepties met betrekking tot vertrouwen valt immers niet noodzakelijkerwijs samen. Voor het algemeen vertrouwen in beloningsbeleid putten we inspiratie uit de vragenbatterijen met betrekking tot procedurale rechtvaardigheid van De Boer et al. (2002) en Sels \& Overlaet (I999). Voorbeelditems zijn: 'Werknemers in mijn organisatie worden steeds fair behandeld met betrekking tot beloning; ' De communicatie omtrent de beloning verloopt altijd open en eerlijk; 'Mijn werkgever is voldoende competent om het 
loonbeleid in onze organisatie vorm te geven'. Specifiek vertrouwen in prestatiemanagement werd gemeten aan de hand van onder andere de volgende items: 'Degene(n) die mijn prestaties of verdiensten moet(en) beoordelen is/zijn voldoende vertrouwd met mijn werk; 'De in mijn organisatie afgesproken evaluatiecriteria worden op een consistente wijze toegepast'. Op basis van de antwoorden op deze items werden telkens ro-puntenschalen geconstrueerd. De chronbach's alpha's van deze schalen bedroegen respectievelijk o,85 (algemeen vertrouwen) en 0,77 (specifiek vertrouwen). Het centrale deel van de vragenlijst werd afgesloten met vragen over interne billijkheid en externe competitiviteit (cf. distributieve rechtvaardigheid) . Deze zijn geïnspireerd op de vragenbatterij van De Boer et al. (2002). Het gaat om vragenitems als: 'In vergelijking met collega's die een vergelijkbare functie uitoefenen in dezelfde organisatie, hoe evalueer je dan je eigen salaris? '; 'In vergelijking met collega's die een vergelijkbare functie uitoefenen in een andere organisatie, hoe evalueer je dan je eigen salaris?'. De chronbach's alpha van deze schaal is $0,67 .^{2}$

Aansluitend werd aan de respondenten nog gevraagd een aantal beloningsvoorkeuren en -aspiraties aan te geven. Aan de hand van telkens twee stellingen moesten zij een gedwongen keuze maken. De ene stelling vertaalde meestal de klassieke beloningspraktijk, de andere stelling maakte allusie op een meer moderne of innovatieve variant. Een voorbeeld:

- Stelling I: In het loonbeleid van mijn organisatie zou ik graag terugzien dat goede presteerders meer verdienen dan slechtere presteerders in gelijksoortige functies.

- Stelling 2: Gelijk loon voor gelijk werk is nog altijd het meest rechtvaardige principe dat een organisatie kan toepassen.

De vragenlijst werd na een pretestfase vervolgens verspreid via een on line mediakanaal (Jobat) met breed publieksbereik in Vlaanderen en via de websites/e-mailacties van de initiatiefnemers van de studie (UAMS/ Hay Group). Deze brede verspreiding leverde uiteindelijk 6947 ingevulde vragenlijsten op. Een hoog aantal, dat bovendien mooi gevarieerd was naar geslacht (43\% man, 57\% vrouw), leeftijd (7\% I8-24 jaar, 3I\% 25-34 jaar, 28\% 35-44 jaar, 25\% 45-54 jaar, 9\%> 54 jaar), opleiding (32\% secundair onderwijs, $44 \%$ hoge school buiten universiteit, $24 \%$ universitair), functieniveau (10\% arbeider, 53\% uitvoerend bediende, $32 \%$ middenkader of professional, $5 \%$ directie of hoger kader) en sector ( $26 \%$ industrie, $35 \%$ dienstverlening en $39 \%$ non-for-profit). Hoewel deze werkwijze geen representativiteit garandeert voor de Vlaamse werkende bevolking, nemen we aan dat de steekproef wel ruim en heterogeen genoeg is om onze onderzoeksvragen op een goede manier te exploreren.

De analyses gebeurden via hiërarchische regressiemodellen en Structural Equation Modeling (SEM). ${ }^{3}$ De regressiemodellen werden opgebouwd 
in drie stappen. In een eerste stap werden het controlemodel (leeftijd, geslacht, functie, sector, grootte van de organisatie, loonklasse) getest. In het tweede model werden bijkomend de centrale onafhankelijke variabelen ingevoerd, behoudens specifiek vertrouwen in prestatiemanagement. In dit model bleven alle 6947 respondenten overeind. In een derde stap werd vervolgens de variabele 'specifiek vertrouwen in prestatiemanagement' ingevoerd. Aangezien niet alle respondenten reeds een systeem van prestatiemanagement (minimaal functionerings- en/of beoordelingsgesprek) kennen, hebben deze modellen betrekking op minder respondenten $(n=5330)$. Aanvullend werd dit laatste model

Het engagement van

Vlaamse werknemers wordt nauwelijks beïvloed door de crisis nog getest via SEM. Het voordeel hiervan is dat de twee afhankelijke variabelen (engagement én verloop) samen in één model getest kunnen worden.

\section{De resultaten}

\section{Impact crisis}

Het engagement van Vlaamse werknemers wordt nauwelijks beïnvloed door de crisis (gemiddelde score voor bevlogenheid ligt op 44 (score tussen 9 en 63/sd=II.I) in 2009; begin 2008 lag dit gemiddelde op 48/ $\mathrm{sd}=\mathrm{II} .5)$. Verwacht werd dat door onzekerheidsgevoelens en crisis-stress ook het engagement van de werknemers tanend was. Onze onderzoeksresultaten bevestigen dit niet. Idem dito voor de verloopcijfers. Van de bevraagde werknemers heeft het afgelopen jaar 47 procent overwogen een andere baan uit te gaan oefenen. Bijna de helft van deze groep heeft ook effectief gesolliciteerd voor een functie buiten de organisatie. Deze percentages zijn vrij stabiel in de tijd. Dat werknemers hondstrouw zijn in tijden van crisis, blijkt dus een fabel te zijn.

\section{Impact eerlijk loon}

Eén op de drie Vlaamse werknemers is ontevreden over de manier van communiceren omtrent beloning. 34 procent vindt dat er in de organisatie geregeld loongerelateerde beslissingen genomen worden gebaseerd op favoritisme; 30 procent is van mening dat werknemers unfair behandeld worden met betrekking tot beloning. Deze en andere cijfers (zie tabel I) wijzen in de richting van wantrouwen in en ontevredenheid over de heersende beloningspraktijken bij een niet gering aandeel van de Vlaamse werknemers. Ook de cijfers ten aanzien van interne billijkheid en externe competitiviteit wijzen in die richting.

Momenteel vindt 38 procent van de respondenten dat hun loon te laag is in vergelijking met collega's die een vergelijkbare functie uitoefenen in dezelfde organisatie. Een relatief hoog percentage, dat nog iets geprononceerder is terug te vinden bij arbeiders $(44,4 \%)$, vrouwen $(39,4 \%)$, 

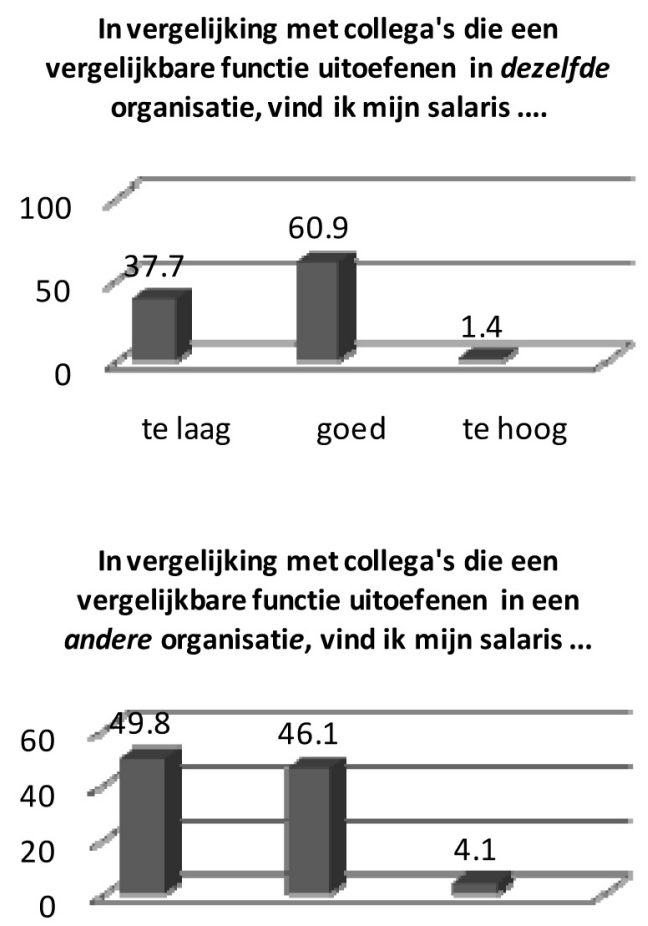

te laag goed te hoog

Figuur 2. Interne billijkheid en externe competitiviteit.

de industriële $(40,9 \%)$ en dienstverlenende sector $(40,2 \%)$, kleinere organisaties (<50 werknemers) (42,1\%), 25-34-jarigen (40,8\%) en bescheiden inkomens (< I500 euro) $(48,7 \%)$. Wat externe competitiviteit betreft, vindt bijna de helft van de respondenten dat hun loon te laag is in vergelijking met collega's die een vergelijkbare functie uitoefenen in een andere organisatie. Vooral werknemers met een beperkt inkomen (tot I500 euro) (60,2\%), uit de not-for-profit sector (51,8\%), vrouwen $(58,5 \%)$ en uitvoerend bedienden (5I,9\%) zijn deze mening toegedaan. Mannen scoren beter op zowel perceptie van interne billijkheid als van externe competitiviteit. Zij zijn relatief vlugger geneigd hun loon - zowel intern als extern - in te schatten als 'goed/in verhouding'. Een en ander heeft wellicht te maken hebben met het feit dat mannen nog steeds in beter betaalde functies en sectoren werkzaam zijn (cf. horizontale en verticale functiesegregatie, zie bijvoorbeeld Sels \& Theunissen, 2006).

Percepties van interne billijkheid en externe competitiviteit gaan vaak hand in hand $(\mathrm{r}=.503 / \mathrm{p}=.000)$. Wanneer werknemers met deze gevoelens van oneerlijke beloningspraktijken kampen, is de kans groot dat ze 


\begin{tabular}{|c|c|}
\hline \multicolumn{2}{|l|}{ Algemeen vertrouwen in beloningsbeleid } \\
\hline & Veeleer/helemaal eens \\
\hline $\begin{array}{l}\text { 1. Werknemers in mijn organisatie worden steeds fair behandeld m.b.t. beloning. } \\
\text { 2. De communicatie omtrent beloning verloopt altijd open en eerlijk. } \\
\text { 3. In mijn organisatie wordt iedere werknemer op een gelijke manier behandeld in } \\
\text { het kader van het loonbeleid. } \\
\text { 4. Mijn werkgever is voldoende competent om het loonbeleid in onze organisatie } \\
\text { vorm te geven. } \\
\text { 5. Mijn werkgever informeert zichzelf goed vooraleer een beslissing m.b.t. beloning } \\
\text { te nemen. } \\
\text { 6. Beloften m.b.t. beloning worden steeds nagekomen in mijn organisatie. }\end{array}$ & $\begin{array}{l}70 \% \\
66 \% \\
66 \% \\
79 \% \\
79 \% \\
77 \%\end{array}$ \\
\hline \multicolumn{2}{|l|}{ Specifiek vertrouwen in prestatiemanagement } \\
\hline $\begin{array}{l}\text { 1. In de beoordelingsprocedure krijg ik voldoende kansen om mijn prestaties te } \\
\text { verduidelijken en te verdedigen. } \\
\text { 2. De criteria die worden gehanteerd bij de beoordeling zijn mij duidelijk. } \\
\text { 3. Degene(n) die mijn prestaties of verdiensten moet(en) beoordelen, is/zijn vol- } \\
\text { doende vertrouwd met mijn werk. } \\
\text { 4. Ik krijg voldoende inzicht in en uitleg bij de resultaten van de extra beloning. } \\
\text { 5. De in mijn organisatie afgesproken evaluatiecriteria worden op een consistente } \\
\text { wijze toegepast. }\end{array}$ & $\begin{array}{l}79 \% \\
73 \% \\
71 \% \\
65 \% \\
61 \%\end{array}$ \\
\hline
\end{tabular}

Tabel 1. Antwoordpercentages algemeen en specifiek vertrouwen.

uitkijken naar een andere job. Algemeen vertrouwen in het beloningsbeleid, samen met de interne en externe billijkheid ervan, blijken immers belangrijke determinanten van verloopintentie, ook ten tijde van crisis. Dit blijkt uit de resultaten van de hiërarchische regressievergelijkingen (zie bijlage I) en het SEM-model (zie bijlage 2).

\section{Resultaten verloopintentie}

Uit stap 2 van het hiërarchische regressiemodel (zie bijlage I) komt naar voor dat het algemeen vertrouwen in beloningsbeleid (of beter nog: de perceptie van procedurale rechtvaardigheid) ( $\beta=-.273)$, samen met een interne billijke en extern competitieve perceptie van het loon (of: de perceptie van distributieve rechtvaardigheid) ( $\beta=-$.I24) een duidelijk significant negatieve impact sorteren op verloopintentie. Daarnaast blijven volgende controlevariabelen in het tweede model $\left(\mathrm{R}^{3}=. \mathrm{I} 7 \mathrm{I}\right)$ overeind: leeftijd, de grootte van de organisatie, het functieprofiel en de loonklasse. Werknemers ouder dan 45 jaar, werknemers uit grotere organisaties (+500 werknemers) en werknemers met een loon tussen I500 en 2000 euro rapporteren significant minder verloopintentie, terwijl uitvoerend bedienden, middenkaders en professionals significant iets hoger scoren. Het vervolgens toevoegen van de variabele 'specifiek vertrouwen in prestatiemanagement' in stap 3 van de regressiemodellen, levert geen toegevoegde waarde op. De variabele blijkt geen impact te hebben in het model van verloopintentie. Ook in het SEM-model (zie bijlage 2) heeft de variabele nauwelijks impact op verloopintentie $(\beta=-.06)$. 


\section{Resultaten engagement}

Het omgekeerde blijkt waar te zijn voor engagement. In model 3 van het regressiemodel (zie bijlage I) $\left(\mathrm{R}^{2}=. \mathrm{I} 37\right)$ is er een relatief sterk verband op te tekenen tussen engagement enerzijds en specifiek vertrouwen in prestatiemanagement anderzijds ( $\beta=$.I99) - 77 procent van de respondenten neemt vandaag de dag deel aan een functionerings-/beoordelingsgesprek. Voor een kleine helft daarvan worden de resultaten van dit gesprek gekoppeld aan een extra beloning. Wanneer werknemers het gevoel krijgen dat binnen deze beoordelingspraktijk het management duidelijke criteria hanteert, deze op een consistente manier toepast, werknemers voldoende kansen biedt om prestaties te verduidelijken en te verdedigen et cetera, dan is de kans groot dat prestatiemanagementpraktijken engagementsverhogend werken.

Interne billijkheid/externe competitiviteit blijkt dan weer geen impact te vertonen op engagement; algemeen vertrouwen in beloningspraktijken wel ( $\beta=$.I3I), maar in relatief mindere mate dan op verloopintentie. Dat blijkt zowel uit de regressiemodellen ( $\beta=. \mathrm{I} 3 \mathrm{I}$ ) als uit het SEM-model ( $\beta=$.I3). Tot slot blijven volgende achtergrondvariabelen overeind met betrekking tot engagement (zie stap 3 van de regressiemodellen): leeftijd en functieprofiel. Oudere werknemers ( $>54$ jaar), bedienden en directieleden blijken significant iets hoger te scoren op engagement.

\section{Dromen mag: prestatiebeloning en broadbanding}

Zoals reeds vermeld, werd in de enquête voorts uitvoerig gepeild naar beloningsvoorkeuren en -aspiraties van werknemers. Respondenten moesten aan de hand van telkens twee stellingen een (gedwongen) keuze maken. Uit deze oefening blijkt vooreerst een (voorzichtig) draagvlak te bestaan voor vormen van pres-

$71 \%$ meent dat een fikse loonsverhoging ook moet kunnen zonder promotie, binnen dezelfde functie tatiebeloning: 62 procent van de respondenten verkiest de stelling 'In het loonbeleid van mijn organisatie zou ik graag terugzien dat goede presteerders meer verdienen dan minder goede presteerders in een gelijkaardige functie' boven 'Gelijk loon voor gelijk werk is nog altijd het meest rechtvaardige principe dat een organisatie kan toepassen'. Vooral mannen (70\%), directieleden $(82 \%) /$ hoger kader (75\%) en werknemers binnen de industriële $(67 \%)$ en dienstverlenende ( $72 \%)$ sectoren kunnen zich vinden in deze eerste stelling. Idem dito voor de stelling: 'Het is niet zozeer anciënniteit die bepalend is voor de evolutie van het loon, andere elementen hebben meer impact' ( $64 \%$ is akkoord).

Een tweede opmerkelijk draagvlak ontwaren we voor een salarisstructuur gebaseerd op brede loonvorken. Een overtuigende meerderheid van onze respondenten (71\%) is van mening dat een fikse loonsverhoging (tussen I2 en $20 \%$ ) ook moet kunnen zonder promotie, binnen dezelfde functie. 
In vakjargon wordt het idee van 'brede loonvorken' ook wel benoemd als broadbanding (zie bijvoorbeeld Armstrong \& Duncan, 200I). Bij broadbanding worden brede functiegroepen ('broad bands') in termen van functiezwaarte gevormd. Hierdoor ontstaat een beperkt aantal functiegroepen, waarin functies van verschillende zwaarte kunnen worden ingedeeld. Bijvoorbeeld: lichte verkoopfuncties onder in de groep en zwaardere senior verkoopfuncties bovenin. Aan een brede functiegroep wordt een loonschaal gekoppeld met een groot verschil tussen schaalminimum en schaalmaximum. Tussen dit minimum en maximum worden bepaalde 'pay zones' (salaristrajecten) gedefinieerd. Bijvoorbeeld een pay zone onder in de schaal voor een beginnend verkoper, een pay zone midden in de schaal voor een allround verkoper en een pay zone boven in de schaal voor een gespecialiseerde senior verkoper. De groei in salaris in pay zones of schaal gebeurt niet met behulp van automatische periodieken, maar op grond van een beoordeling van de individuele prestatie en ontwikkeling. De lijnmanager bepaalt het groeipercentage of -bedrag waarmee de werknemer verder groeit in de schaal.

\section{Maar niet extreem: wat is, is goed}

De oefening in beloningsvoorkeuren toont verder aan dat Vlaamse werknemers vrij behoudend zijn wat betreft beloningspraktijken. Wat is, is goed en daar hoeft niet per se aan getornd te worden. Een aantal voorbeelden ter illustratie. De stelling 'Hoe ouder ik word, hoe meer ik wil verdienen' (72\%) wint het boven 'Hoe ouder ik word, hoe meer bereid $\mathrm{ik}$ ben in te leveren op mijn loon of loonsverwachtingen bij te stellen, in ruil voor bijvoorbeeld minder werkdruk of verantwoordelijkheid' (29\%). Het idee van landingsbanen waarbij gradueel minder (hard) wordt gewerkt op het einde van de loopbaan, wordt door onze respondenten niet overweldigend gesteund, ook niet door de vrouwelijke respondenten. Integendeel, het idee van een gestaag stijgende looncurve lijdt een hardnekkig bestaan bij Vlaamse werknemers. Waar prestatiebeloning een beginnend draagvlak kent, is dit zeker nog niet het geval voor beloning op basis van competenties/groeipotentieel. Slechts 24 procent is ervan overtuigd dat bij gelijk presteren, de persoon met groter groeipotentieel meer mag verdienen. Velen houden de boot dan ook nog af wanneer het aankomt op een rechtstreekse link tussen talent- en beloningsmanagement. Ook met betrekking tot het cafetariaplan zijn de meningen eerder verdeeld. De ene helft wil vrijheid in keuze van voordelen (bijvoorbeeld mobiele telefoons, maaltijdcheques, verzekeringen) en pleit dus voor het cafetariaplan, de andere helft wil vooral eenzelfde pakket voordelen voor gelijkaardige functies in de organisatie. Momenteel heeft slecht 5\% van de bevraagden ervaring met een cafetariaplan. Hoewel een klassiek concept met merites op het vlak van motivatie (zie bijvoorbeeld Langedijk, I998), is de inburgering ervan in de Vlaamse beloningspraktijk slechts beperkt. 
Ook de inbedding van onze beloningsstructuren in het sociale sectoroverleg en in de cao's kent bijval bij acht van de tien werknemers. Het Angelsaksische systeem waarbij individuele werkgevers (meer) vrijheid hebben in het zelf bepalen van loonschalen zonder hierbij rekening te (moeten) houden met afspraken op een ruimer niveau, verdient slechts bij een minderheid de voorkeur. Vlamingen zijn gehecht aan hun collectief loonbeleid en de inbedding ervan in een sterk uitgebouwd sociaal overlegsysteem. Vooral vrouwen (81\%), arbeiders $(84 \%)$ en werknemers uit de not-for-profit sector (84\%) zijn gewonnen voor het collectieve systeem. Vlaamse werknemers laten voorts niet graag in hun (belonings) kaarten zien. Haaks op de Angelsaksische opendeurpolitiek (iedereen weet van iedereen hoeveel hij of zij verdient) wenst de meerderheid van onze respondenten dat over lonen de nodige discretie aan de dag gelegd wordt (60\%). Opvallend is dat vooral directieleden/hoger kader (7I\%) deze mening is toegedaan. Zij zijn geen vragende partij in het transparant maken van hun (top)lonen.

Ten slotte blijven Vlaamse werknemers hardnekkig geloven in jaarlijkse loonsverhogingen (hoe klein ook). Het enkele jaren wachten (op een grotere verhoging)

Dat werknemers hondstrouw zijn ten tijde van crisis blijkt een fabel geniet slechts bij een minderheid van de respondenten de voorkeur. Zelfs in tijden van crisis blijft 52 procent geloven dat er ruimte moet blijven voor loonsonderhandeling/extra beloning. Vooral vrouwelijke respondenten (54\%), arbeiders (58\%) en uitvoerend bedienden (56\%) zijn deze mening toegedaan. Tevens opmerkelijk is dat de meerderheid van de respondenten $(78 \%)$ verwacht dat leidinggevenden zelf spontaan loonsverhogingen voorstellen. Vlaamse werknemers zijn niet geneigd zelf het initiatief te nemen voor een loonsverhoging. Zij stellen zich veeleer afwachtend op.

Bovenstaande keuzepatronen zijn samen te vatten in een index van o tot Io. De o staat dan voor een zeer behoudsgezinde score of nog: een score die een zeer sterke voorkeur reflecteert voor de klassieke/gekende beloningspraktijken. Io is het spiegelbeeld en symboliseert een radicale voorkeur voor innovatieve beloningspraktijken. Gemiddeld gezien scoren Vlaamse werknemers 4,3 op Io (sd=-1.6). Dit resultaat is in lijn met de eerder gesignaleerde behoudsgezinde reflex op de beloningsrealiteit. Werknemers in de dienstverlening $(4,6)$, mannen $(4,7)$, midden- en hogere kaders $(4,7 / 5)$, 35-44-jarigen $(4,3)$ en goedverdieners $(4,8)$ scoren significant iets hoger op de index, wat wil zeggen dat zij ietwat gedurfdere beloningsverwachtingen koesteren.

\section{Conclusies en reflecties voor de toekomst}

Retentie van (top)talent blijft belangrijk en wordt in perioden van laagconjunctuur zelfs belangrijker. Dat werknemers hondstrouw zijn ten tijde van crisis, blijkt immers een fabel, zo bleek uit de Engagement Study 
2009. In deze studie stond het verband centraal tussen percepties van distributieve en procedurale rechtvaardigheid enerzijds, verloopintentie en engagement anderzijds. Opvallend hierbij was dat distributieve rechtvaardigheid gemeten in termen van interne billijkheid/externe competitiviteit geen of nauwelijks significante impact heeft op engagement. Dit staat deels haaks op de verwachtingen, aangezien er verondersteld werd dat de perceptie van een eerlijke beloning een positieve impact zou hebben op werkengagement. Deels bevestigt dit resultaat het vermoeden dat het eerlijk-loonthema veeleer een retentie- dan een engagementthema is. Drijvende factoren voor engagement liggen veeleer op het domein van kwaliteit van arbeid en leiderschap dan op het domein van beloning (De Prins et al., 2007; Macey \& Schneider, 2008). Hier staat tegenover dat engagement wel sterk wordt beïnvloed door een specifiek vertrouwen in prestatiemanagement.

Prestatiemanagement en engagement gaan hand in hand, mits een aantal spelregels op het vlak van werknemersvertrouwen worden gerespecteerd. Deze hebben te maken met transparantie, consistentie en gedegenheid. Gecombineerd met het draagvlak dat er bestaat voor prestatiebeloning, pleit dit resultaat voor meer HR-aandacht richting performance management. Herhaald wordt dat een belangrijke voorwaarde hiervoor wel is dat werknemers voldoende vertrouwen hebben in het systeem van prestatiebeloning en -management. Het design van het performance managementsysteem moet dan ook met de nodige omzichtigheid gebeuren. Bamps et al. (2008) merken hierover op dat voor iedereen duidelijk moet zijn wie (g)een beloning krijgt en waarom niet/wel? Werknemers mogen niet voor verassingen komen te staan wat hun loonsverhoging of bonus betreft. Ook mag er rond de beloningen geen taboesfeer hangen. Open communicatie hierover is wenselijk. Dit zou kunnen betekenen dat werknemers aan de hoogte van hun loon kunnen zien hoe ze het doen in vergelijking met hun peers binnen de organisatie, alsook met zichzelf in het verleden. Hiertoe kan HR aan de werknemers de nodige informatie ter beschikking stellen, bijvoorbeeld over de positie van het loon van de betreffende medewerker binnen de salarisband of ten opzichte van het relatieve midpoint. Bovendien is het belangrijk dat indien bepaalde afgesproken prestaties worden geleverd, de beloning ook daadwerkelijk volgt. Aangewezen is ook dat organisaties er goed over nadenken of zij naast de prestaties en competenties nog andere factoren laten meespelen bij de berekening van de bonus of de loonsverhoging, en zo ja welke (aanwezigheid, evaluatiescores, resultaten van de onderneming, enz.).

Distributieve en algemene procedurale rechtvaardigheid blijken vooral impact te hebben op verloopintentie. Opvallend hierbij is dat bijna de helft van onze respondenten vindt dat hun loon te laag is in vergelijking 
met collega's die een vergelijkbare functie uitoefenen in een andere organisatie. Hierin ligt een belangrijke uitdaging voor managers en HR-professionals. Deze percepties kunnen in de organisatie immers een hardnekkig bestaan leiden met een negatieve spiraal in termen van verloop tot gevolg. Een objectivering van het debat door middel van onder andere regelmatige benchmark (cf. salarisenquêtes) zowel wat betreft het loonniveau als de loonmix kan hierin mogelijk soelaas brengen. Belangrijk is dat werknemers betrokken worden bij dit soort van vergelijkingen. Wanneer deze te geïsoleerd gebeuren binnen de organisatie, is de kans groot dat deze informatie onvoldoende (juist) doorsijpelt naar de werknemers. Wanneer blijkt uit de externe benchmark dat de organisatie afwijkt, is het belangrijk dat werknemers weten waarom dit zo is. Hiervoor kunnen goede redenen bestaan. Meer algemeen gesteld blijven transparantie (eerlijkheid/openheid), communicatie en inspraak hefbomen bij uitstek in een beloningsbeleid/bedrijfsklimaat dat werknemersvertrouwen hoog in het vaandel draagt. De Lange en Koppens (2007) spreken in dit verband in meer algemene termen van de duurzame arbeidsrelatie binnen high trust organisaties; het accent verschuift van een gezagsrelatie - die overigens wel blijft bestaan - naar een samenwerkingsrelatie op basis van wederzijds vertrouwen. Er is sprake van 'volwassen arbeidsrelaties', waarbij medewerkers betrokken worden bij en inspraak hebben in thema's als beloning, arbeidstijd en flexibiliteit.

Voorts vindt 38 procent van de respondenten dat hun loon te laag is in vergelijking met collega's die een vergelijkbare functie uitoefenen in dezelfde organisatie. Reden van dit ongenoegen vinden onze respondenten vooral terug bij hun (betere) prestaties, hun opgenomen verantwoordelijkheid en de extra inspanningen die ze leveren. Om tegemoet te komen aan deze verzuchtingen kunnen innovatieve beloningssystemen als prestatiebeloning (zie eerder) en brede loonvorken soelaas brengen. In dit laatste systeem komt het idee van een horizontale (professionele/ experten) loopbaan (versus de klassieke verticale management loopbaan) om de hoek kijken. Carrière maken hoeft dan niet per se via de gekende verticale kanalen. Ook binnen een zelfde brede functie kan men een junior-expertloopbaan uitbouwen en/of steeds meer multi-inzetbaar worden.

Het feit dat de not-for-profit sector relatief beter scoort op interne billijkheid, toont aan de andere kant ook aan dat klassieke, transparante functiewaarderingssystemen een even heilzaam effect kunnen sorteren op het vlak van (perceptie van) interne billijkheid. De opbouw van een logische en harmonische loonstructuur, waarin werknemers langs bepaalde banen naar hoger gekwalificeerde functies met hogere lonen kunnen opklimmen, kan in bepaalde organisatiecontexten een gezonde 
carrièreprogressie bij het personeel stimuleren en hierdoor leiden tot minder verloop. Een adequaat intern beloningssysteem hoeft dus niet voor iedereen en overal een even trendy invulling te krijgen. Vlaamse werknemers zijn over het algemeen immers vrij behoudsgezind wat loonbeleid betreft. Wat is, is goed en daar hoeft niet per se aan getornd te worden. Deze behoudsgezindheid is even belangrijk om als HRmanager mee rekening te houden. Aangenomen kan worden dat het weinig opbrengt te investeren in innovatieve beloningssystemen, wanneer werknemers hierop hoegenaamd niet zitten te wachten.

\section{Literatuur}

Adams, J.S. (1965). Inequity in social exchange. In: Advances in Experimental Social Psychology. 2, 267-299.

Ambrose, M.L. (2002). Contemporary justice research: a new look at familiar questions. Organizational Behavior and Human Decision Process, 89, 803-8I2.

Armstrong, M. \& Duncan, B. (200I). New Dimensions in Pay Management. Trowbridge: Cromwell Press.

Aryee, S., Budhwar, P.S. \& Chen, Z.X. (2002). Trust as a mediator of the relationship between organizational justice and work outcomes: test of a social exchange model. Journal of Organizational Behavior, 23, 3, 267-285.

Bamps, H., Hellings, S. \& Roelandt, P. (2008). Informatiedossier. Prestatiebeloning. Brussel: SERV/STV-Innovatie \& Arbeid.

Colquitt, J.A., Conlon, D.E., Wesson, M.J., Porter C.O.L.H. \& NG, K.Y. (200I). Justice at the Millennium: a meta-analytic review of 25 years of organizational Justice research. Journal of Applied Psychology, 86, 3, 425-445.

De Boer, E.M., Bakker, A.B., Syroit, J.E. \& Schaufeli, W.B. (2002). Unfairness at work as a predictor of absenteeism. In: Journal of Organizational Behavior, 23, I8I-I97.

De Lange, W. \& Koppens, J. (2007). De duurzame arbeidsorganisatie. Amsterdam: WEKA Uitgeverij BV.

De Prins, P., Brouwers, S. \& Maloens, M. (2007). Wat als loon niet werkt? Hefbomen voor engagement en retentie anno 2007. In: Tijdschrift voor HRM, IO, 4, 7-2I.

Dirks, K.T. \& Ferrin, L.F. (200I). The role of trust in organizational settings. Organization Science, I2, 4, 450-467.

Dirks, K.T. \& Ferrin, D.L. (2002). Trust in leadership: meta-analytic findings and implications for research and practice. Journal of Applied Psychology, 87, 6Iт-628.

Finn, R.H., Lee, S.M. (1972). Salary Equity. its determination, analysis, and correlates. Journal of Applied Psychology, 56, 283-292.

Greenberg, J. (1990). Organizational Justice: yesterday, today and tomorrow. Journal of Management, I6, 2, 399-432.

Hannisch, K.A. \& Hulin, C.L. (I990). Job attitudes and organizational withdrawal: an examination of retirement and other voluntary withdrawal behaviors. Journal of Vocational Behavior, 37, 60-78. 
Hendrix, W.H. \& Spencer, B.A. (1989). Development and test of a multivariate model of absenteeism. Psychological Reports, 64, 923-958.

Kahn, W.A. (I990). Psychological conditions of personal engagement and disengagement at work. The Academy of Management Journal, 33, 4, 692-724.

Lievens, F. (2007). Handboek Human resource Management. Leuven: Lannoo Campus.

Macey, W.H. \& Schneider B. (2008). The Meaning of Employee Engagement. Industrial and Organizational Psychology, I, 3-30.

May, D.R., Gilson, R.L. \& Harter, L.M. (2004). The psychological conditions of meaningfulness, safety and availability and the engagement of the human spirit at work. Journal of Occupational and Organizational Psychology, 77, II-37.

Mayer,R.C., Davis, J.H. \& SChoorman, F.D. (I995). An integrative model of organizational trust. Academy of Management Review, 20, 3, 709-734.

Schaufeli, W. \& Bakker, A. (200I), Werk en welbevinden. Naar een positieve benadering in de arbeids- en gezondheidspsychologie. Gedrag en organisatie, I4, I5, 22-253.

Schaufeli, W. \& Bakker, A. (2003). UWES. Utrecht Work Engagement Scale. Manual. Utrecht: Occupational Health Psychology Unit.

Schoorman, F.D., Mayer, R.C. \& Davis, J.H. (2007). An integrative model of organizational trust: past, present and future. Academy of Management Review, 32, 2, 344-354.

Sels, L. \& Overlaet (I999). Lonen in Vlaanderen. Leuven: Acco.

Sels, L. \& Theunissen, G. (2006), Waarom vrouwen beter verdienen maar mannen meer krijgen - Een kritisch essay over de sekseloonkloof, Leuven/Voorburg: Acco.

Wierks, T. (2006). HRM en rechtvaardigheid: welke antecedenten zijn bepalend? Tilburg: faculty of Social end Behavioural Sciences. Dpt. Human Resources Studies. People Management Centre.

\section{Noten:}

I. De drie engagementstudies kennen telkens een gemeenschappelijk luik (bevraging onafhankelijke variabelen engagement en verloop) en een specifiek luik (bevraging afhankelijke variabelen):

- 2007: algemene scope beloning, leiderschap, kwaliteit van arbeid, work/life balance, ontwikkelingsmogelijkheden, werkomgeving,

- 2008: specifieke scope op leiderschap,

- 2009: specifieke scope op beloning.

2. Wat de onderlinge relaties tussen de onafhankelijke variabelen betreft: er bestaat een redelijk sterk significant verband tussen algemeen vertrouwen en specifiek vertrouwen $\left(r=. .56_{3} / \mathrm{p}=.000\right)$ en een iets minder sterk maar significant verband tussen distributieve rechtvaardigheid en algemeen vertrouwen $(\mathrm{r}=.383 / \mathrm{p}=.000)$ en specifiek vertrouwen $(\mathrm{r}=.258 / \mathrm{p}=.000)$.

3. Structural equations modeling (SEM) is de naam voor een multivariate methode waarmee men complexe causale modellen kan schatten en toetsen. In deze modellen kunnen in principe meerdere onafhankelijke, mediërende en afhankelijke variabelen tegelijkertijd voorkomen. In ons model komen enkel onafhankelijke en afhankelijke variabelen voor. Het voordeel is dat de twee afhankelijke variabelen (engagement én verloop) samen in één model getest kunnen worden. 
Bijlage 1. De impact van werknemersvertrouwen op engagement en verloop: resultaten van hiërarchisch regressie ( $\beta)$.

\begin{tabular}{|c|c|c|}
\hline & Verloopintentie & Engagement \\
\hline $\begin{array}{l}\text { Stap } 1 \text { (controlemodel) } \\
\text { 1. Leeftijd (referentie=18-24 jarigen) } \\
\text { a. } 24-25 \text { jaar } \\
\text { b. } 35-44 \text { jaar } \\
\text { c. } 45-54 \text { jaar } \\
\text { d. Ouder dan } 54 \text { jaar } \\
\text { 2. Functie (referentie=arbeider) } \\
\text { a. Uitvoerend bediende } \\
\text { b. Middenkader/professional } \\
\text { c. Directie/hoger kader } \\
\text { 3. Sector (referentie=industrie) } \\
\text { a. Dienstverlening } \\
\text { b. Not-for-profit } \\
\text { 4. Grootte organisatie (referentie }=<50 \text { ) } \\
\text { a. } 50-199 \\
\text { b. } 200-499 \\
\text { c. } 500 \text { of meer } \\
\text { 5. Loonklasse (referentie=tot 1500) } \\
\text { a. } \quad 1500-2000 \\
\text { b. } 2000-2500 \\
\text { c. } 2500-3000 \\
\text { R } 2\end{array}$ & $\begin{array}{c}\mathrm{ns} \\
\mathrm{ns} \\
-.109 \\
-.194 \\
.074 \\
.060 \\
\mathrm{~ns} \\
\mathrm{~ns} \\
-.076 \\
\mathrm{~ns} \\
\mathrm{~ns} \\
-.064 \\
-.061 \\
-.058 \\
\mathrm{~ns} \\
.066\end{array}$ & $\begin{array}{c}-.141 \\
-.067 \\
\mathrm{~ns} \\
\mathrm{~ns} \\
.205 \\
\mathrm{~ns} \\
.120 \\
\mathrm{~ns} \\
\mathrm{~ns} \\
\mathrm{~ns} \\
-.068 \\
-.069 \\
\mathrm{~ns} \\
.047 \\
\mathrm{~ns} \\
.075\end{array}$ \\
\hline $\begin{array}{l}\text { Stap } 2 \text { (zonder specifiek vertrouwen) } \\
\text { 1. Algemeen vertrouwen } \\
\text { 2. Interne billijkheid/externe competitiviteit } \\
\text { 3. Leeftijd (referentie=18-24 jarigen) } \\
\text { a. } 24-25 \text { jaar } \\
\text { b. } 35-44 \text { jaar } \\
\text { c. } 45-54 \text { jaar } \\
\text { d. Ouder dan } 54 \text { jaar } \\
\text { 3. Functie (referentie=arbeider) } \\
\text { a. Uitvoerend bediende } \\
\text { b. Middenkader/professional } \\
\text { c. Directie/hoger kader } \\
\text { 4. Sector (referentie=industrie) } \\
\text { a. Dienstverlening } \\
\text { b. Not-for-profit } \\
\text { 5. Grootte organisatie (referentie }=<50 \text { ) } \\
\text { a. } 50-199 \\
\text { b. } 200-499 \\
\text { c. } 500 \text { of meer } \\
\text { 6. Loonklasse (referentie=tot } 1500 \text { ) } \\
\text { a. } 1500-2000 \\
\text { b, } 2000-2500 \\
\text { c. } 2500-3000 \\
\text { R } 2\end{array}$ & $\begin{array}{l}-.272 \\
-124 \\
\mathrm{~ns} \\
\mathrm{~ns} \\
-.110 \\
-.192 \\
.114 \\
.058 \\
\mathrm{~ns} \\
\mathrm{~ns} \\
\mathrm{~ns} \\
\mathrm{~ns} \\
\mathrm{~ns} \\
-.075 \\
-.046 \\
\mathrm{~ns} \\
\mathrm{~ns} \\
.171\end{array}$ & $\begin{array}{c}.203 \\
\mathrm{~ns} \\
-.091 \\
\mathrm{~ns} \\
.061 \\
.086 \\
\\
.180 \\
.052 \\
.143 \\
\mathrm{~ns} \\
\mathrm{~ns} \\
\mathrm{~ns} \\
-.075 \\
-.072 \\
\mathrm{~ns} \\
\mathrm{~ns} \\
\mathrm{~ns} \\
.119\end{array}$ \\
\hline
\end{tabular}


Tijdschrift voor HRM 22010

\begin{tabular}{|l|c|c|}
\hline Stap 3 (met specifiek vertrouwen) & & \\
1. Algemeen vertrouwen & -.254 & .131 \\
2. Specifiek vertrouwen & $\mathrm{ns}$ & .199 \\
3. Interne billijkheid/externe competitiviteit & -.139 & $\mathrm{~ns}$ \\
4. Leeftijd (referentie=18-24 jarigen) & .078 & -.119 \\
a. 24-25 jaar & $\mathrm{ns}$ & $\mathrm{ns}$ \\
b. 35-44 jaar & -.104 & $\mathrm{~ns}$ \\
c. 45-54 jaar & -.186 & .093 \\
d. Ouder dan 54 jaar & & \\
5. Functie (referentie=arbeider) & .108 & .173 \\
a. Uitvoerend bediende & $\mathrm{ns}$ & $\mathrm{ns}$ \\
b. Middenkader/professional & $\mathrm{ns}$ & .143 \\
c. Directie/hoger kader & $\mathrm{ns}$ & $\mathrm{ns}$ \\
6. Sector (referentie=industrie) & $\mathrm{ns}$ & $\mathrm{ns}$ \\
a. Dienstverlening & $\mathrm{ns}$ & $\mathrm{ns}$ \\
b. Not-for-profit & $\mathrm{ns}$ & $\mathrm{ns}$ \\
7. Grootte organisatie (referentie =<50) & -.066 & $\mathrm{~ns}$ \\
a. 50-199 & & $\mathrm{ns}$ \\
b. 200-499 & $\mathrm{ns}$ & $\mathrm{ns}$ \\
c. 500 of meer & $\mathrm{ns}$ & $\mathrm{ns}$ \\
8. Loonklasse (referentie=tot 1500) & .070 & .137 \\
a. 1500-2000 & & \\
b. 200-2500 & .167 & \\
c. 2500-3000 & & \\
R 2 & & \\
&
\end{tabular}


Bijlage 2. Resultaten van SEM: het gehele model getest.

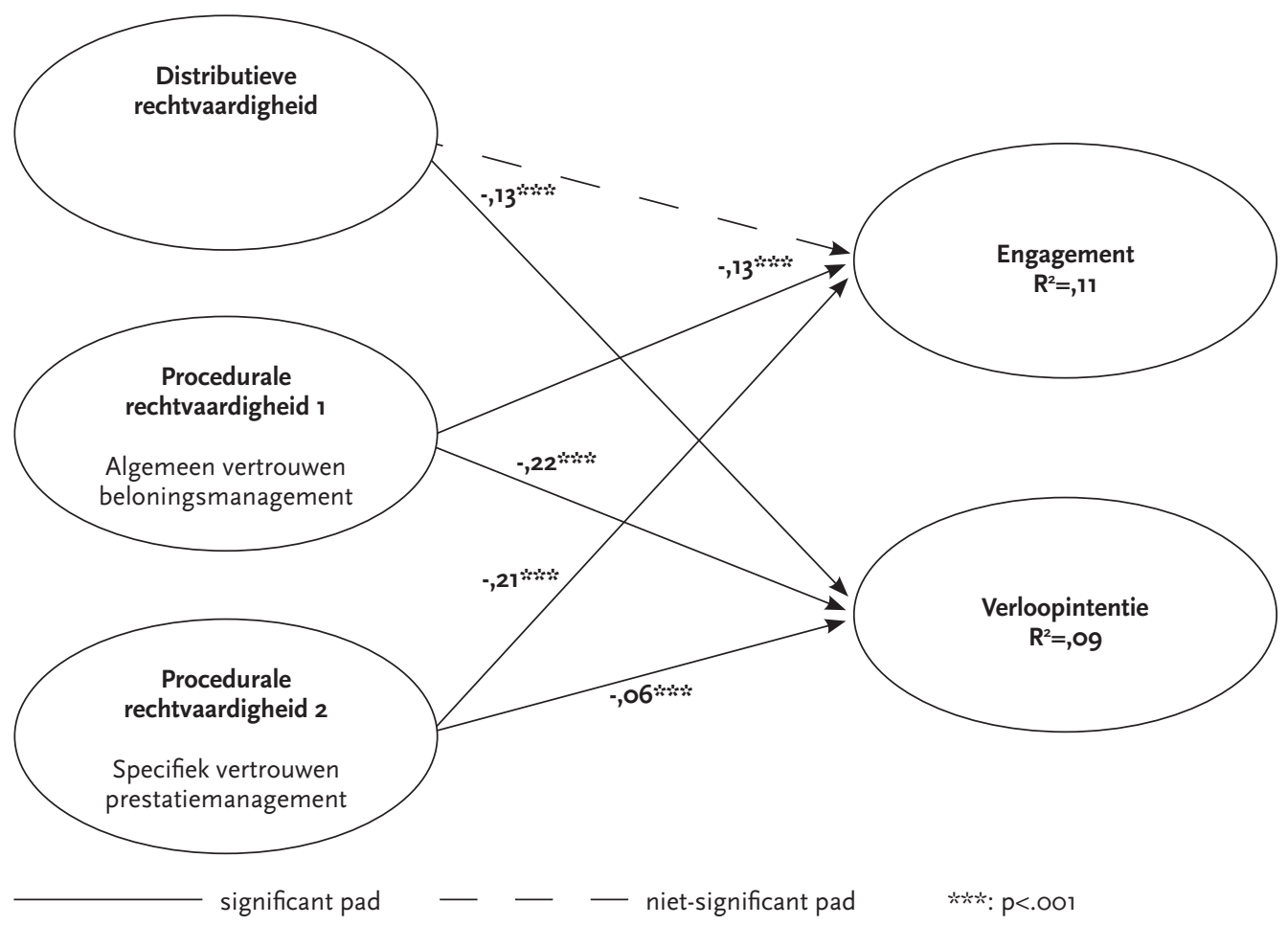

